Discussion Paper No. 05-40

\title{
The Effects of Changes in the
} Unemployment Compensation System on the Adoption of IT by Older Workers

Alexandra Spitz

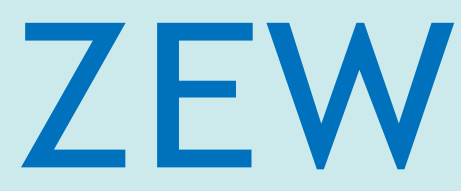

Zentrum für Europäische Wirtschaftsforschung $\mathrm{GmbH}$

Centre for European

Economic Research 
Discussion Paper No. 05-40

\title{
The Effects of Changes in the Unemployment Compensation System on the Adoption of IT by Older Workers
}

\author{
Alexandra Spitz
}

Download this ZEW Discussion Paper from our ftp server:

\author{
ftp://ftp.zew.de/pub/zew-docs/dp/dp0540.pdf
} Das Papier entstand im Rahmen des Forschungsprojekts „IKT-Einsatz und die Altersstruktur der Beschäftigten“
im Auftrag der Landesstiftung Baden-Württemberg.

The paper was written as part of the research project "ICT usage and the age structure of employees" commissioned by the Landesstiftung Baden-Württemberg foundation.

Die Discussion Papers dienen einer möglichst schnellen Verbreitung von neueren Forschungsarbeiten des ZEW. Die Beiträge liegen in alleiniger Verantwortung der Autoren und stellen nicht notwendigerweise die Meinung des ZEW dar.

Discussion Papers are intended to make results of ZEW research promptly available to other economists in order to encourage discussion and suggestions for revisions. The authors are solely responsible for the contents which do not necessarily represent the opinion of the ZEW. 


\section{Non-technical Summary}

During the 1980s and 1990s several law changes in the unemployment compensation system were enacted in Germany affecting certain groups of workers, leaving the remainder of the labor force unaffected. This paper takes advantage of the experiment provided by these law changes to analyze the question of whether the observed lower probability of information technology (IT) usage among older workers is due to a lack of ability or whether incentives are important in this respect.

The theoretical link between the unemployment compensation system and the adoption of new technology is the disincentive to invest in human capital provided by an extension of the generosity of the system. Extensions of the maximum entitlement period of unemployment benefits for elderly workers, in particularly those that allow the elderly a smooth transition from unemployment to retirement, reduce the incentives to invest in human capital, first, by reducing the net return of the investment and, second, by reducing the period of time that the investment is rented out.

Using a differences-in-differences strategy, I show that the computer usage rates of different age groups closely match the law changes. In 1979, when the maximum entitlement period for unemployment benefits was 12 months for all employees, IT usage rates were flat over all ages. During the 1980s and mid-1990s, when the unemployment compensation system got more generous for increasingly younger employees, the growth rates of IT usage of affected groups decreased accordingly. By contrast, after the reform in April 1997, which cut back the generosity of unemployment benefits, affected groups catched up in terms of IT usage.

These results suggest that incentives are potentially more important in explaining lower diffusion rates of IT among elderly employees than innate abilities. 


\title{
The Effects of Changes in the Unemployment Compensation System on the Adoption of IT by Older Workers\$
}

\author{
AlexAndRA SpItz*
}

May 2005

\begin{abstract}
Two main hypotheses can be found in literature on why elderly workers have a lower probability of using information technology than their younger peers: lower learning capabilities and reduced incentives to invest in human capital. I use law changes in the unemployment compensation system enacted in Germany during the 1980s and 1990s to demonstrate that "incentives" are more important than "capabilities" in determining variation in IT usage. Elderly workers only fell behind the IT usage rates of their younger peers during the 1980s and 1990s, when unemployment benefits got increasingly generous, thereby reducing their incentives to invest in human capital.
\end{abstract}

JEL-classification: J14, J24

Keywords: differences-in-differences, computer adoption by older workers, changes in unemployment compensation system

\footnotetext{
$\S$ Acknowledgments: The paper was written as part of the research project "ICT and the Age Structure of Older Workers" commissioned by the Landesstiftung Baden-Württemberg foundation. Helpful comments by Irene Bertschek, Thomas Hempell, Edwin Leuven and Susanne Prantl are gratefully acknowledged.
}

*ZEW Mannheim, Research Group Information and Communication Technologies, P.O. Box 103443, D-68034 Mannheim, Germany, email: spitz@zew.de 


\section{Introduction}

During the 1980s and 1990s several law changes in the unemployment compensation system were enacted in Germany affecting certain groups of workers, leaving the remainder of the labor force unaffected. This paper takes advantage of the experiment provided by these law changes to analyze the question of whether the observed lower probability of information technology (IT) usage among older workers is due to a lack of ability or whether incentives are important in this respect.

The disincentives of unemployment benefits have often been discussed in the context of the debate over differences in the level of unemployment between Europe and the United States, and also in the debate over the causes of long-term unemployment 1 However, the disincentives are also important in the context of the acquisition of human capital necessary when employees have to adapt themselves to changes in skill requirements brought about by, for example, the introduction of IT in the workplace. Extensions of the maximum entitlement period of unemployment benefits for elderly workers, in particularly those that allow the elderly a smooth transition from unemployment to retirement, reduce the incentives to invest in human capital, first, by reducing the net return of the investment and, second, by reducing the period of time that the investment is rented out.

In Germany, the labor force participation of older workers has declined tremendously in the last three decades ${ }^{2}$ About 70 percent of workers aged 60-64 were employed in 1970 , this figure has declined to 33 percent in 2000. The labor force participation rate of workers aged 55-59 followed a similar trend, though not as pronounced: about 88 percent worked in 1970 and 78 percent in 2000. Compared to the labor force participation of older employees in other OECD countries, these figures largely correspond to the OECD average. On average about 39 percent of employees aged 55-64 were employed in OECD countries in 2001, compared to 37 percent in Germany. However, countries such as Sweden and Denmark still have a labor participation rate of 67 (57 respectively) percent among this group of workers.

The trend in the labor force participation rate in Germany arrests special attention since it concurred with changes in the age structure of the population. The downward trend in the birthrate since the 1970s together with the increase in life expectancy resulted in an increased proportion of older people in the population. This is not a development specific to Germany. However, Germany is one of the countries in which the degree of this trend is most pronounced. The labor market consequence is that the support ratio, that is the number of gainfully employed persons per consumer, declines. This decline has a substantial impact not only on the functioning of the social system but also on economic growth.

Economic research as well as conventional wisdom often attribute the decline in the labor force participation of older workers to the rapid technological change in recent decades,

\footnotetext{
${ }^{1}$ See, for example, Layard, Nickell and Jackman (1991), Hunt (1995) and Fitzenberger and Wilke (2004).

${ }^{2}$ See, for example, Clemens, Künemund and Parey (2003).
} 
in particular to the wide spread of information technologies (IT) in the workplace. $3^{3}$ Older workers are not able to cope with the changing skill requirements associated with the introduction of IT in the workplace, so the usual argument. This view is supported by the observation, that older workers have a lower probability to use IT on the job.

In this paper, I take a different view. I argue that lower learning capabilities are likely not the causal factors that resulted in elderly workers having a low aptitude to use IT. It is rather the manifold changes in unemployment benefits for elderly unemployed in the 1980s and 1990s that affected the IT usage rates of elderly workers. These reforms have reduced the incentives for elderly workers to adapt their human capital to the changing skill requirements..$^{4}$

The empirical analysis in this paper shows that elderly workers only fell behind the IT usage rates of younger workers in the mid-1980s, thus at a time when the maximum entitlement periods of unemployment benefits was extended for increasingly younger age cohorts in Germany, giving them (in the extreme case) the possibility to have a smooth transition from unemployment to (early) retirement. The results from a differences-indifferences approach closely match the trend of law changes. That is, up to the mid-1990s, when the unemployment compensation system got increasingly generous for certain age groups, the diffusion rate of computers declined among those affected. By contrast, age groups affected by the cut down of the generosity of the unemployment compensation system after the reform in April 1997, have started to catch up again on computer usage. These results suggest that incentives are potentially more important in explaining lower diffusion rates of IT among elderly employees than innate abilities.

This paper is structured as follows: In the next section, I discuss the related literature and introduce the theoretical reasoning. In Section ??, I describe the data sets used in the analyses and introduce the variables of main interest. Section 4 presents and discusses the empirical results. In Section 5, I draw conclusions.

\section{Theoretical Background}

In recent decades, the proportion of workers of all ages using IT increased from 6 percent in 1979 to more than 55 percent in 1999 5 However, the spread of IT in the workplace has not taken place uniformly between different age groups. Among employees aged 58-64 the IT usage rate was 45 percent in 1999, about 10 percent below the average. Studies on the company level show that IT-intensive companies have lower fractions of older workers

\footnotetext{
${ }^{3}$ Of course, retirement schemes also have an important impact on the labor force participation of the elderly, see, for example, Börsch-Supan and Schnabel (1999). For a discussion of the recent reforms in the German retirement system, see Berkel and Börsch-Supan (2004).

${ }^{4}$ This view is similar to the one expressed by Friedberg (2003) who focused on impending retirement. For an analysis of changing skill requirements brought about by IT see Autor, Levy and Murnane (2003) and Spitz (2004).

${ }^{5}$ See Table 1
} 
(Bertschek, 2004) and that new technologies reduce the hiring possibilities of older workers (Aubert, Caroli and Roger, 2004). At the same time, the labor force participation rate of elderly workers decreased tremendously. These observations resulted in the hypothesis that elderly workers are not able to cope with the changes in skill requirements brought about by the introduction of IT in the workplace.

In this paper, I take the view that the fact whether or not older workers use IT is a question of incentives rather than of the possession of certain abilities or capabilities ${ }^{6}$ Working with IT got much easier over time as most software programs are extremely user-friendly in these days. However, the empirical evidence that will be presented in Section 4 for West Germany suggests that computer usage rates were flat over most age groups early on and only started to diverge in the mid-1980s.7 The amazing thing about this observation is that older workers seem to have been capable of keeping up with technological changes when the usage of IT was relatively demanding in terms of technology specific skills, they only have fallen behind when the technology started to become more and more userfriendly. This notion suggests that something else than capabilities or abilities determines the IT usage rates of the elderly. As already noted, my conjecture is that incentives play an important role in this respect. I am going to analyze this notion using law changes in the unemployment compensation system that have largely affected the incentives of certain age groups to invest in human capital, leaving other age groups unaffected.

The standard text book model of the timing in human capital demonstrates this argument. ${ }^{8}$ At every age, an employee will invest in human capital up to the point were the marginal revenue of the investment equals marginal costs. The changes in unemployment law considered in this analysis have affected the marginal return of human capital investments. The marginal return (MR) of an investment for an employee aged $a$ is:

$$
M R_{a}=R+\frac{R}{1+r}+\frac{R}{(1+r)^{2}}+\frac{R}{(1+r)^{3}}+\ldots+\frac{R}{(1+r)^{n}}
$$

where $n=65-a$ (assuming the employee retires with 65, the official retirement age in Germany) is the number of times the investment will be rented out, $\mathrm{r}$ is the discount rate and $R$ is the net return. Thus, MR is the present discounted value of future net returns of the investment. Expanding the generosity of unemployment benefits for employees of a certain age ceteris paribus reduces MR, first, by reducing $n$ and, second, by reducing $R$. Net returns are reduced since the fall back option gets financially more attractive. The reduction in $n$ is illustrated most impressively for employees who, in addition of having

\footnotetext{
${ }^{6}$ The analyses by Borghans and ter Weel (2002) suggest, for example, that older workers do not have more trouble using a computer than their younger peers. Weinberg (2002) even comes to the conclusion that part of the human capital formed by work experience is complementary to computer usage.

${ }^{7}$ The age profiles of computer usage in West Germany are surprisingly similar to those for the U.S. reported by Friedberg (2003) and Card and DiNardo (2002).

${ }^{8}$ See, for example, Borjas (2000, p. 261ff).
} 
Table 1: Computer Usage at Work: Percentage of Workers Who Use a COMPuTER

\begin{tabular}{ccccc}
\hline \hline & \multicolumn{4}{c}{ Years } \\
& 1979 & $1985 / 86$ & $1991 / 99$ & $1998 / 99$ \\
\hline All Workers & 5.58 & 18.35 & 34.97 & 55.78 \\
Age Groups: & & & & \\
$25-35$ & 7.20 & 21.40 & 38.62 & 57.46 \\
$35-41$ & 6.19 & 20.68 & 40.78 & 58.82 \\
$42-43$ & 4.54 & 23.47 & 36.68 & 58.93 \\
$44-48$ & 4.01 & 16.76 & 39.06 & 57.16 \\
$49-57$ & 3.69 & 13.78 & 29.97 & 56.05 \\
$58-64$ & 3.42 & 14.66 & 21.91 & 45.26 \\
Education: & & & & \\
Low & 3.33 & 10.25 & 16.36 & 26.69 \\
Medium & 5.83 & 20.07 & 34.05 & 54.87 \\
High & 11.07 & 25.45 & 60.74 & 82.64 \\
Gender: & & & & \\
Male & 6.01 & 18.79 & 36.12 & 55.86 \\
Female & 4.64 & 17.59 & 33.17 & 55.67 \\
Sample Size: & 22538 & 22860 & 21071 & 22900 \\
\hline \hline
\end{tabular}

a longer duration of unemployment benefit owing to the law changes, directly enter early retirement subsequent to the unemployment spell..$^{9}$

\section{Data Sets}

The analysis is based on the "Qualification and Career Survey" and the SOEP.

The "Qualification and Career Survey" is a survey of employees carried out by the German Federal Institute for Vocational Training (Bundesinstitut für Berufsbildung, BIBB) and the Research Institute of the Federal Employment Service (Institut für Arbeitsmarkt- und Berufsforschung, IAB). It includes four cross-sections launched in 1979, 1985/86, 1991/92 and 1998/99 each covering about 30,000 individuals (men and women) 10

\footnotetext{
${ }^{9}$ Since 1986 the unemployed older than 58 have the possibility to receive unemployment benefits even if they commit not to search for a job. Owing to the reforms in the mid-1980s, employees who lose their jobs at the age of 55 are able to reach the critical age of 59 without interruption of unemployment benefit transfers. They then continue to receive unemployment benefits until they are entitled for transfers from the pension system.

${ }^{10}$ The target population is not uniform within the four waves. Due to this changing sample design the sample used in the present study had to be restricted to West-German residents with German nationality,
} 
The most important variable for the present analysis is the measure of computer usage. The data set includes detailed information on the tools and machines used by the employees at the workplace. I generated a dummy variable for computer usage when employees indicated that they use computers, terminals or electronic data processing machines on the job.

Other variables included in the analysis are:

Age: The survey includes information about the year of birth. I calculated the age of employees using the survey year $(1979,1985,1991,1998)$ and substracting the year of birth.

Formal Educational Attainment: The data set contains detailed information on the vocational attainment of employees. The employees are classified into three qualification groups according to their vocational education (school qualifications are not considered).11

- People with low levels of education, that is people with no occupational training.

- People with medium level of education, that is people with a vocational qualification who might have either completed an apprenticeship or graduated from a vocational college.

- People with high level of education, that is, people holding a degree from a university or technical college.

These variables are dummy variables, taking on the value 1 if the employee falls within the particular education level.

Description of SOEP

\section{Empirical Results}

Table 11 shows the pattern of computer usage of employees aged 25-64 based on the $\mathrm{BIBB} / \mathrm{IAB}$ data set. In 1979, close to 6 percent of employees used a computer at the workplace. This proportion rose by about 13 percentage points to more than 18 percent in $1985 / 86$. The diffusion rate of IT at the workplace even increased thereafter with the result that about 35 percent used IT in 1991/92 and about 55 percent in 1998/99. Table 1 also shows how IT usage differs between various groups of workers. For example, more

in other words East-German residents and non-German employees are excluded from the sample since these groups of employees were not interviewed in every wave. Moreover, the sample does not include self-employed and unemployed persons, employees with agricultural occupations and employees working in the agricultural sector. In addition, persons younger than 25 and older than 64 are excluded from the sample.

\footnotetext{
${ }^{11}$ Most studies on West Germany use this classification rather than years of schooling because it is more appropriate to the system of vocational training. See Card (1999) for a detailed discussion of different measures of education in different institutional settings.
} 
than 82 percent of employees with a degree from a university or a technical college used IT at the workplace in 1998/99, whereas only about 27 percent of employees with no vocational training did. The gap in the qualification-specific IT usage rate even widened between 1979 and 1998/99. Contrary to the findings in other countries, IT usage is larger among West German men than women. However, the size of this difference is rather small.

\subsection{Computer Usage and Age}

Figure 1 shows the age profile of IT usage in the four cross-sections. The profile is flat over all ages in 1979 and also over most ages in 1985/86. The proportion of IT users was about 7 (19) percent for employees younger than 50 in 1979 (1985/86), and about 3 (14) percent for employees older than 50. The difference in IT usage rates of employees younger and older than 50 was the most pronounced in 1991/92, when 37 percent of employees younger than 50 used IT on the job and 25 percent of employees older than 50 . This difference in usage rates had declined to 6 percentage points in 1998/99 (younger than 50: 56 percent; older than 50: 50 percent). Comparing the age profiles over time suggests that the trend towards higher usage rates of IT was constant across ages between 1979 and 1985/86. It was only at the beginning of the 1990s that the pace of computer diffusion was lower for employees older than mid-40 relative to their younger peers. The age profiles were flat in earlier cross-sections and have the largest curvature in 1991/92. But each age profile has flat ranges for employees aged 25-45.

The structure of the age profiles suggests that "age" is not the determining factor of IT usage. The flat age profile in 1979, for example, shows that the elderly workers had nearly the same aptitude of using IT than their younger peers. This is really intriguing as computer technology was far less user-friendly back then. By contrast, the use of computers required programming skills. It is very unlikely that employees aged 55 in 1979 learnt to program computers in school or during their vocational training. They learnt to use computers as needed on the job. Why then should the elderly in later crosssections be less capable to work with IT, in particular as the technology got increasingly user-friendly? 
This notion is corroborated by the evolution of IT usage across birth cohorts. Figure 2 shows, for example, the evolution of IT usage of employees born in 1949 who were 50 years old in 1999, 43 years in 1992, 37 years in 1986 and 30 in 1979. The development of IT usage of this group of employees does not suggest that they lagged behind the overall trend towards increased computer usage. Employees born in 1939 did not have lower IT usage rates in 1979 (when they were 40) than their younger peers. However, the pace of IT diffusion of this birth cohort lagged behind thereafter.

Table 2 shows the gains of computer use among successive cohorts. Focusing attention to the cohorts in 1998/99 shows that the pace of computer diffusion decreases with age of cohorts (moving horizontally within the same row). For example, between 1979 and 1985/86 the rate of computer usage increased by 15.8 percentage points for employees aged 44-48, 13.7 percentage points for employees aged 49-57 and 11.2 percentage points for employees older than 58. The figures also show that employees age 58-64 in 1998/99 kept close to younger employees between 1979 and 1985/86. However, the pace of computer diffusion among this group of employees remained constant between 1985/86 and 1991/92 when the pace of computer diffusion accelerated among younger workers. Between 1991/92 and 1998/99 employees both aged 49-57 and aged 58-64 had a faster computer diffusion rate than employees aged 44-48.

Table 2: The Spread of Computers among Older Cohorts: Change in Computer Usage Rates by Cohorts and Years, in Percentage Points

\begin{tabular}{lccccc}
\hline \hline & \multicolumn{5}{c}{ Computer Usage by Cohorts aged: } \\
\hline & $35-41$ & $42 / 43$ & $44-48$ & $49-57$ & $58-64$ \\
\hline $\begin{array}{l}\text { Cohorts in 1985/86 } \\
\text { Change, 1979-1985/86 }\end{array}$ & 13.62 & 15.87 & 10.67 & 9.55 & 10.98 \\
Cohorts in 1991/92 & & & & & \\
$\quad$ Change, 1979-1985/86 & & 14.85 & 13.06 & 11.64 & 9.19 \\
Change, 1985/86-1991/92 & 17.83 & 14.84 & 18.57 & 12.9 & 8.83 \\
Cohorts in 1998/99 & & & & & \\
Change, 1979-1985/86 & & & 15.76 & 13.74 & 11.22 \\
Change, 1985/86-1991/92 & & 15.39 & 18.99 & 17.09 & 12.07 \\
Change, 1991/92-1998/99 & 19.35 & 21.2 & 15.2 & 18.27 & 16.82 \\
\hline \hline
\end{tabular}

The previous results suggest that the pace of IT diffusion among older cohorts only started to fall behind when the cohorts approach the retirement age, or, as it was the case in the mid-1980s, when owing to the extension of the maximum entitlement periods of unemployment benefits the present discounted value of returns from investment in human capital decreased.

Table 3 summarizes the maximum entitlement periods for unemployment benefits under the different regimes. Before 1985, the maximum entitlement period for unemployment 
benefits was 12 month ${ }^{12}$ Beginning in January 1985, several law changes came into force which extended the duration of unemployment benefits for elderly workers. At the time of the second cross-section in this study, 1985/86, employees older than 49 received unemployment benefits up to 18 month. At the time of the third cross-section, 1991/92, the maximum entitlement period was extended for employees aged 42 or older. As is shown in Table 3, employees aged 42/43 received unemployment benefits up to 18 month, those aged 44-48 up to 22 months, those aged 49-53 up to 26 months, and those older than 53 for up to 32 months. It was only by a reform in April 1997 that the generous unemployment schemes were restricted again. By the time of the last cross-section in this study, 1998/99, there was again a maximum entitlement period of unemployment benefits of 12 months for all unemployed younger than 44. For those aged 44-48 the maximum entitlement period was 16 months, 21 months for those aged 49-53, and 28 months for those older than 53 .

Table 3: Maximum Entitlement Periods for Unemployment Benefits under DifFERENT RULES

\begin{tabular}{lccccc}
\hline \hline Age of employees: & $<42$ & $42 / 43$ & $44-48$ & $49-53$ & $>53$ \\
\hline Until Dec. 1984 & 12 & 12 & 12 & 12 & 12 \\
Jan. 85-Dec. 85 & 12 & 12 & 12 & 18 & 18 \\
Jan. 86- Dec. 87 & 12 & 12 & 16 & 20 & 24 \\
July 87- April 97 & 12 & 18 & 22 & 26 & 32 \\
After April 97 & 12 & 12 & 16 & 21 & 28 \\
\hline \hline
\end{tabular}

See Plaßmann, 2002

Age as the regressor of main interest is "exogenous", everybody ages with the passage of time. However, in this study "age" is a proxy for the incentive employees have to invest in human capital. Following this interpretation, the law changes provide exogenous variation in the explanatory variable "age" by the disincentives to invest in human capital associated with these law changes.

Figure 3 shows the average computer usage rates of age categories, defined by their affectedness by the law changes in different waves. The numbers above the lines indicate the maximum entitlement period of unemployment benefits for the respective age category and the respective year. The average computer usage rate closely match the law changes. This notion is corroborated by the differences-in-differences (DID) estimates shown in Table 4 .

The DID estimator $\hat{\beta}$ is defined as $\hat{\beta}=\left(\bar{Y}_{B, 2}-\bar{Y}_{B, 1}\right)-\left(\bar{Y}_{A, 2}-\bar{Y}_{A, 1}\right)$, with $\bar{Y}_{A, i}$ denoting the average computer usage of the control group (A) before $(i=1)$ and after $(i=2)$ the reform $\left(\bar{Y}_{B, i}\right.$ is defined similarly for the treated group, B). One of the appealing properties of this approach is that the DID estimator can be computed in a regression of stacked micro data including interaction terms equal to the product of a dummy indicating observations

\footnotetext{
${ }^{12}$ See Hunt (1995, p.91) for a detailed discussion of the German unemployment compensation system.
} 
after the reform. In addition, the regression framework can be augmented by including individual characteristics $X_{i}$ suspected to have time-varying effects.

The equation underlying the regression shown in Table 4 is:

$Y_{i t}=\beta_{1} t_{85 / 86}+\beta_{2} t_{91 / 92}+\beta_{3} t_{98 / 99}+\gamma_{1} a g e_{42 / 43}+\gamma_{2} a g e_{44-48}+\gamma_{3} a g e_{49-53}+\gamma_{4} a g e_{(>=54)}+$ $\alpha_{1} a e_{42 / 43} * t_{91 / 92}+\alpha_{2} a g e_{44-48} * t_{91 / 92}+\alpha_{3} a g e_{44-48} * t_{98 / 99}+\alpha_{4} a_{g e_{49-53}} * t_{85 / 86}+\alpha_{5} a g e_{49-53} *$ $t_{91 / 92}+\alpha_{6} a e_{49-53} * t_{98 / 99}+\alpha_{7} a g e_{(>=54)} * t_{85 / 86}+\alpha_{8} a g e_{(>=54)} * t_{91 / 92}+\alpha_{9} a g e_{(>=54)} * t_{98 / 99}+$ $X_{i}^{\prime} \delta_{0}+\epsilon_{i}$,

where $Y_{i t}$ represents a dummy variable indicating computer usage of individual i at time t. Thus, $Y_{i t}$ is regressed on dummies indicating waves $\left(t_{85 / 86}-t_{98 / 99}\right)$ and age groups $\left(a e_{42 / 43}-a g e_{(>=54)}\right)$ as well as interaction terms indicating age categories after the law changes. The reference category are the untreated individuals $($ age $<42)$ and the cross-section before the first reform (1979). The differences-in-differences strategy allows me to assess the impact of the law changes on the probability to work with computers ${ }^{13}$ The regression shown in column (1) of Table 4 includes no further controls, that shown in column (2) additionally includes controls for education, gender and occupations ("regression-adjusted" DID approach). The controls are included in order to circumvent that age differences in occupations, education groups and also between women and men are erroneously attributed to age differences in computer usage.

The coefficients for the different waves reflect the time trend in computer usage. The coefficient for the age categories indicate that computer usage was lower for employees older than 44 than for their younger peers. The most important results are those for the interaction terms. For example, the interaction term for the age group 42-43 with the wave 91/92 dummy is significantly negative indicating that the law change in July 1987, which was in effect until April 1997 and increased the maximum entitlement period of unemployment benefits for employees aged 42-43 from 12 to 18 month, lowered the relative computer usage rates for this group of employees, as would be expected. Owing to the inclusions of the controls, this result is even clearer both in terms of the size of the effect as well as in terms of the precision of the estimates (column 2). The coefficients for the interaction terms of the age category 54-64, for whom the maximum entitlement period increased up to April 1997 and decreased thereafter, are all significantly negative, with the size of the coefficient increasing up until wave 91/92 and decreasing thereafter. Thus, not only the sign of the coefficients match the law changes, but also the size.

\footnotetext{
${ }^{13}$ For applications of the differences-in-differences strategy in other contexts see, for example, Hunt (1995) and Card and Krueger (1994).
} 
Figure 1: Computer Usage at Work, By Age

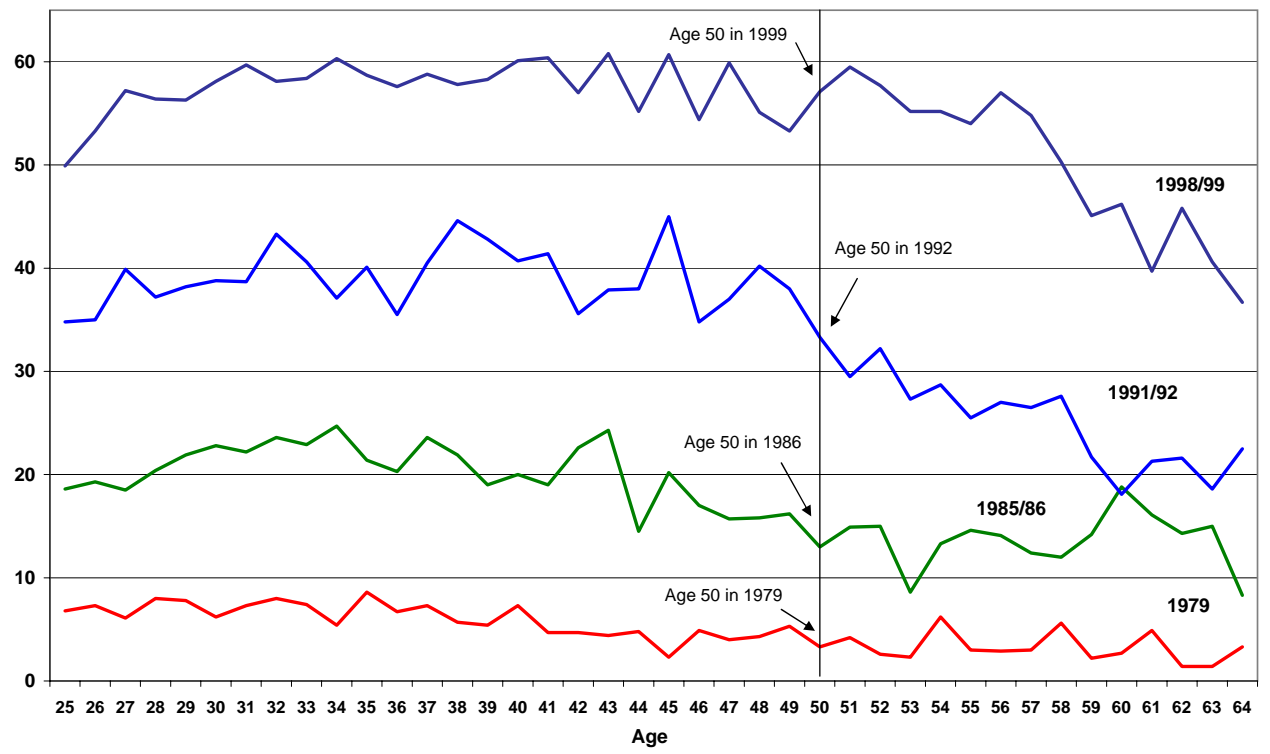

Figure 2: Computer Usage AT Work, By 1999 Cohorts

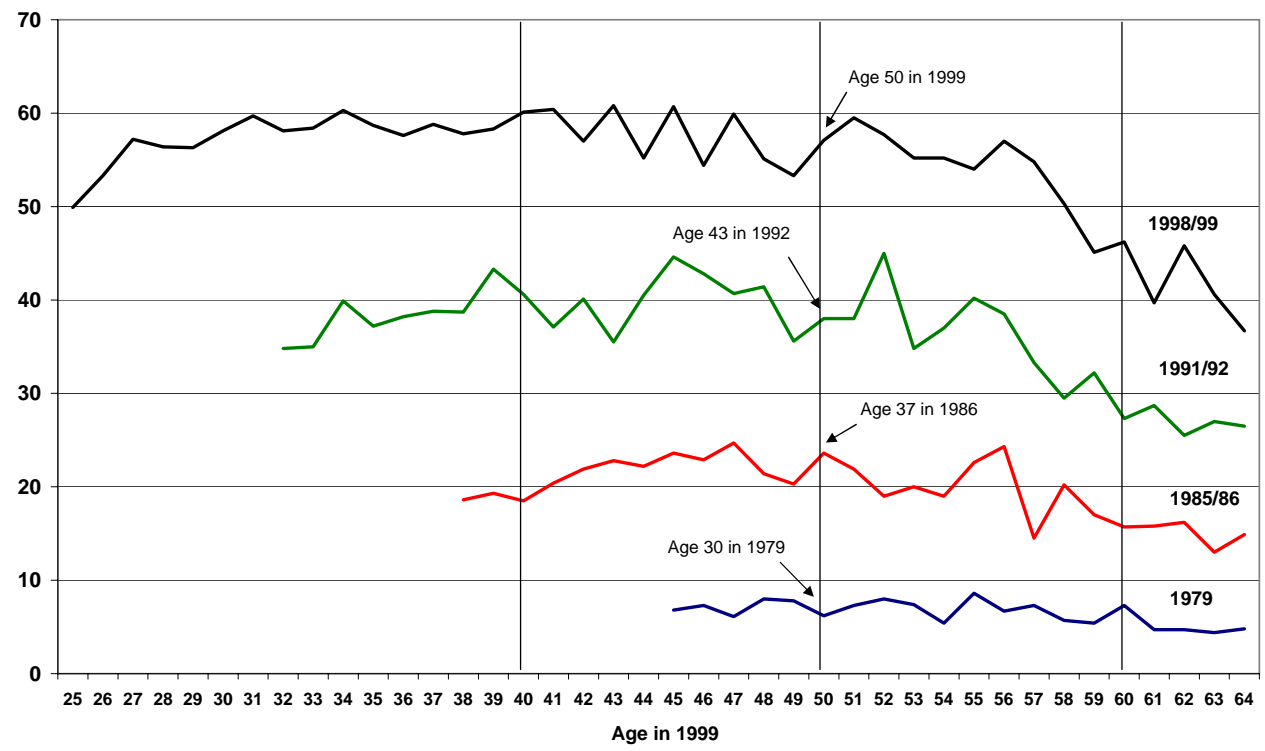


Figure 3: Computer Usage at Work, By Age

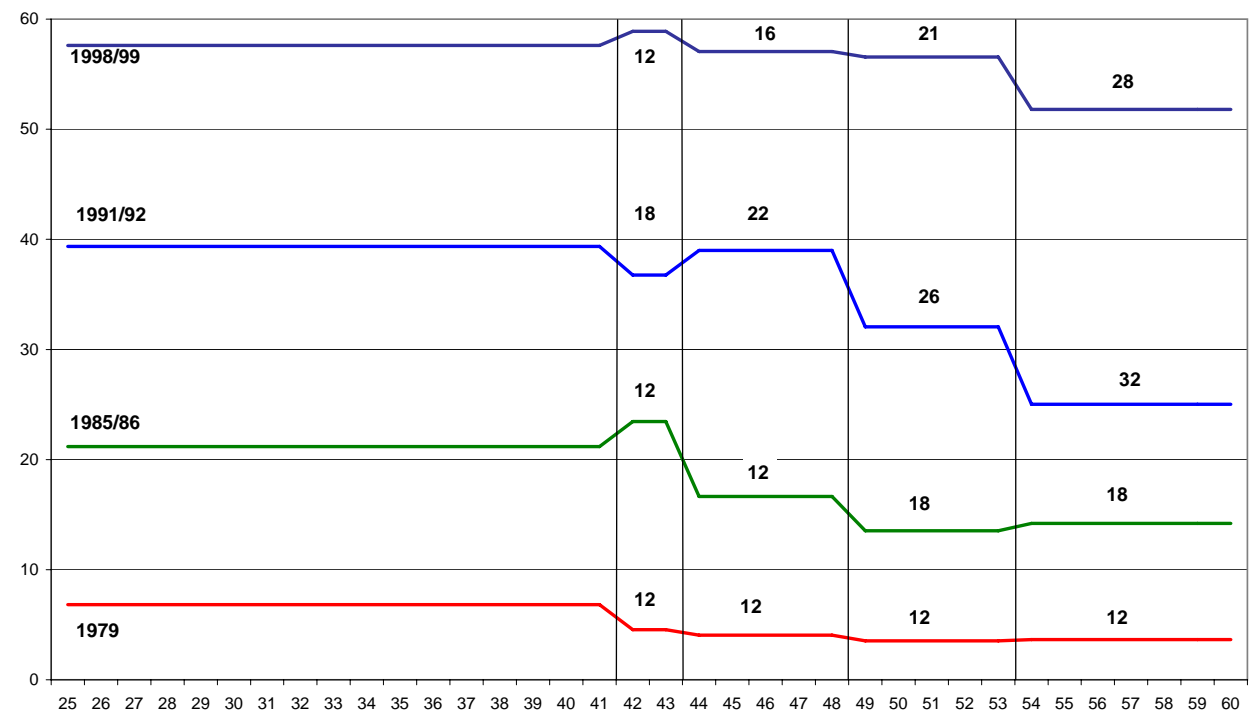

Age 
Table 4: Effects of Changes in Unemployment Benefits on Computer Usage

\begin{tabular}{|c|c|c|}
\hline & \multicolumn{2}{|c|}{$\begin{array}{c}\text { Dep. Variable: Do You Use a Computer at Work? } \\
\text { Coefficients (Robust Std. Err.) }\end{array}$} \\
\hline & (1) & $\overline{(2)}$ \\
\hline \multirow[t]{2}{*}{ wave $85 / 86$} & $0.145^{* * *}$ & $0.146^{* * *}$ \\
\hline & $(0.004)$ & $(0.004)$ \\
\hline \multirow[t]{2}{*}{ wave $91 / 92$} & $0.326^{* * *}$ & $0.322^{* * *}$ \\
\hline & $(0.005)$ & $(0.005)$ \\
\hline \multirow{2}{*}{ wave $98 / 99$} & $0.513^{* * *}$ & $0.515^{* * *}$ \\
\hline & $(0.005)$ & $(0.004)$ \\
\hline \multirow[t]{2}{*}{ Aged 42-43 } & 0.001 & 0.006 \\
\hline & $(0.006)$ & $(0.006)$ \\
\hline \multirow[t]{2}{*}{ Aged 44-48 } & $-0.036^{* * *}$ & $-0.010 * *$ \\
\hline & $(0.005)$ & $(0.004)$ \\
\hline \multirow[t]{2}{*}{ Aged 49-53 } & $-0.031^{* * *}$ & -0.001 \\
\hline & $(0.004)$ & $(0.005)$ \\
\hline \multirow[t]{2}{*}{ Aged 54-64 } & $-0.031^{* * *}$ & $-0.010^{* *}$ \\
\hline & $(0.006)$ & $(0.005)$ \\
\hline \multirow[t]{2}{*}{ Aged $42-43^{*}$ wave $91 / 92$} & $-0.028^{*}$ & $-0.034^{* * *}$ \\
\hline & $(0.016)$ & $(0.014)$ \\
\hline \multirow{2}{*}{ Aged $44-48^{*}$ wave $91 / 92$} & $0.033^{* * *}$ & -0.005 \\
\hline & $(0.012)$ & $(0.011)$ \\
\hline \multirow[t]{2}{*}{ Aged $44-48^{*}$ wave $98 / 99$} & $0.027^{* *}$ & -0.000 \\
\hline & $(0.011)$ & $(0.009)$ \\
\hline \multirow[t]{2}{*}{ Aged $49-53^{*}$ wave $85 / 86$} & $-0.042^{* * *}$ & $-0.040 * * *$ \\
\hline & $(0.010)$ & $(0.009)$ \\
\hline \multirow[t]{2}{*}{ Aged $49-53^{*}$ wave $91 / 92$} & $-0.042^{* * *}$ & $-0.061^{* * *}$ \\
\hline & $(0.011)$ & $(0.010)$ \\
\hline \multirow[t]{2}{*}{ Aged $49-53^{*}$ wave $98 / 99$} & -0.015 & $-0.024^{* * *}$ \\
\hline & $(0.012)$ & $(0.010)$ \\
\hline \multirow[t]{2}{*}{ Aged $54-64^{*}$ wave $85 / 86$} & $-0.040 * * *$ & $-0.029 * * *$ \\
\hline & $(0.009)$ & $(0.009)$ \\
\hline \multirow[t]{2}{*}{ Aged $54-64^{*}$ wave $91 / 92$} & $-0.117^{* * *}$ & $-0.101^{* * *}$ \\
\hline & $(0.010)$ & $(0.009)$ \\
\hline \multirow[t]{2}{*}{ Aged $54-64^{*}$ wave $98 / 99$} & $-0.049 * * *$ & $-0.074^{* * *}$ \\
\hline & $(0.011)$ & $(0.010)$ \\
\hline Controls & No & Education, Gender, Occupation \\
\hline$R^{2}$ & 0.222 & 0.402 \\
\hline Number of Observations & 83132 & 82962 \\
\hline
\end{tabular}

The sample includes workers aged 25-64 with residence in West Germany and of German nationality. 
Comparing the results from column (1) and (2) indicates that age differences in occupations or education classifications do not explain age differences in computer usage. The overall results are even more clear cut in column (2) owing to the inclusion of controls.

The key assumption of the differences-in-differences strategy is that the interaction terms are zero in the absence of the intervention. Thus, a potential pitfall of this strategy is that computer usage may have evolved differently across age categories regardless of the law changes. However, as noted earlier in this paper, there were no significant differences in computer usage across age categories in 1979 when the maximum entitlement period for unemployment benefits was equally large for employees of all ages. In addition, in 1998/99, when the generosity of unemployment benefits has started to become more alike again across age groups, differences in computer usage across age groups also started to become more alike.

The most important disadvantage of the data set is that it only includes employed people, therefore neglecting the unemployed. This is particularly cumbersome for the question of interest in this study since the law changes were targeted specifically on the unemployed across age categories. However, this fact would be a problem for the analysis if there were systematic differences in how computer users and computer non-users responded to the law changes. The impact of the law changes would, for example, be overestimated if computer users had reacted more elastically to the law changes than computer non-users. The decrease in computer usage rates within age groups observed after the respective age group had been affected by the law change would then be mechanically, only reflecting the larger outflow of computer users from the labor market owing to the law changes.

We use the SOEP data to check whether there are systematic differences in the labor market outflow rates of computer users and computer non-users. Table 5 shows how the employment pattern of employees aged 50-62 in 1997 evolves over time, and how this pattern differs between computer users and computer non-users. About 90 percent of employees working in 1997 were still employed in 1998. This figure is reduced to slightly more than 50 percent in 2003. In each year, the employment probability is larger for computer users than for computer non-users. This result thus suggest that computer users rather have a lower probability to leave the labor force than computer non-users, indicating that the estimated impact of law changes on computer usage of the elderly is rather underestimated than overestimated in this study.

The observation that computer users have a higher probability of staying in the labor market is not new, it has even contributed to the notion that the greater labor market attachment of this group of employees is caused by the computer use.

We further investigate the question of whether or not computer users have a stronger labor market attachment on the individual level. Table 6 shows the results of OLS regressions in which a dummy variable indicating that someone who worked in 1997 was still working in the successive years is regressed on computer use. Panel A shows the results when only age is controlled for in the specification, in Panel B three dummies for educational attainment and a dummy for female employees are additionally included as controls. Except for the results in 2000 and 2003 (Panel B) all the coefficients are positive, although not always 
significant. The size of the coefficients indicate that computer user were 3.7 percentage points less likely than computer non-users to have stopped working in 1999.

Although these correlations are already informative for the analysis of the first part of this chapter in the sense that the results there are very unlikely to be driven by computer users having a higher probability to leaving the labor force, they do not allow a conclusion regarding the question of whether computer usage is the causal factor in determining the employment decision of employees. Following Friedberg (2003) we use average computer usage of prime-age employees in the same occupation ${ }^{14}$ High computer usage in occupations signals that computers are productive relative to training costs, so that even older workers are more likely to use them. Table 7 shows the results of the first stage regression. Average computer usage of prime-age employees within the same occupation is a good predictor of computer usage of older employees. Table 8 reports the instrumental variable estimates. The size and the significance of coefficients increase considerably. The point estimates in Panel A imply that using a computer made someone 8.9 percent more likely to "still working" in 1998, 5.8 percent more likely in 1999 and 3.4 percent more likely in 2000. The results suggest that computer usage has an impact on the employment decision in the short run rather than in the long run. The significance of these results drop considerably owing to the inclusion of additional controls (Panel B). The coefficients are even negative for 2002 and 2003. However, they are estimated very imprecise.

The result that the IV estimates are larger than the OLS estimates suggests that computer non-users retired later the higher the computer intensity within the occupation. Although this result raises the concern about omitted factors that are correlated with average computer use of prime-age workers and that influence the employment decision of older workers, it is informative regarding the question of whether technological changes has induced the decline in the labor force participation rate of the elderly.

\section{Table 5: Among People Working in 1997, the Percentage Still Working THE FOLLOWING YeARS}

\begin{tabular}{lcccccc}
\hline \hline \multicolumn{7}{c}{ Proportion of Employees Working in 1997 Still Working in... } \\
\hline \multirow{2}{*}{ All employees aged 50-62 in 1997 } & $\ldots 1998$ & $\ldots 1999$ & $\ldots 2000$ & $\ldots 2001$ & $\ldots 2002$ & $\ldots 2003$ \\
Computer User & 94.1 & 82.1 & 74.8 & 66.0 & 57.7 & 51.2 \\
Computer Non-User & 86.5 & 76.6 & 80.8 & 71.3 & 64.8 & 57.7 \\
\hline \hline
\end{tabular}

Sample: Soep-Data. Number of employees aged 50-62 in 1997 with information about the employment status until 2003 in the sample is 769 .

\footnotetext{
${ }^{14}$ Friedberg (2003) additionally used average computer usage of prime-age workers in the same industry as instrument. However, in regressions not shown here (but available from the authors upon request), we find that this instrument is only weakly correlated with computer usage of older workers in Germany. Therefore, we focus on average computer usage in occupations in this study.
} 
Table 6: OLS Regressions Explaining "Still Working"

\begin{tabular}{|c|c|c|c|c|c|}
\hline & \multicolumn{5}{|c|}{ Dep. Variable: Person is Still Working in... } \\
\hline & ...1998 & $\ldots 1999$ & $\ldots 2000$ & $\ldots 2002$ & $\ldots 2003$ \\
\hline Panel A: & & & & & \\
\hline Computer User & $\begin{array}{c}0.028 \\
(0.023)\end{array}$ & $\begin{array}{c}0.037^{* * *} \\
(0.015)\end{array}$ & $\begin{array}{l}-0.004 \\
(0.015)\end{array}$ & $\begin{array}{c}0.079^{* *} \\
(0.039)\end{array}$ & $\begin{array}{c}0.042 \\
(0.046)\end{array}$ \\
\hline Controls & Age & Age & Age & Age & Age \\
\hline Panel B: & & & & & \\
\hline Computer User & $\begin{array}{c}0.018 \\
(0.023)\end{array}$ & $\begin{array}{c}0.038^{* * *} \\
(0.016)\end{array}$ & $\begin{array}{l}-0.005 \\
(0.015)\end{array}$ & $\begin{array}{c}0.036 \\
(0.043)\end{array}$ & $\begin{array}{l}-0.015 \\
(0.052)\end{array}$ \\
\hline Controls & $\begin{array}{l}\text { Age, Educ., } \\
\text { Gender }\end{array}$ & $\begin{array}{l}\text { Age, Educ., } \\
\text { Gender }\end{array}$ & $\begin{array}{l}\text { Age, Educ., } \\
\text { Gender }\end{array}$ & $\begin{array}{l}\text { Age, Educ., } \\
\text { Gender }\end{array}$ & $\begin{array}{l}\text { Age, Educ., } \\
\text { Gender }\end{array}$ \\
\hline
\end{tabular}

Sample: Soep-Data. Number of employees aged 50-62 in 1997 with information about the employment status until 2003 and information about computer usage is 765 . Robust standard errors are in parentheses.

Table 7: First-Stage Regression

\begin{tabular}{|c|c|}
\hline \multicolumn{2}{|c|}{ Dep. Variable: Computer Usage in 1997} \\
\hline $\begin{array}{l}\text { Proportion of prime age workers using } \\
\text { computers within the same occupation }\end{array}$ & $\begin{array}{c}0.792^{* * *} \\
(0.060)\end{array}$ \\
\hline Controls & Age \\
\hline Partial $R^{2}$ (excl. instruments) & 0.400 \\
\hline F-Test $(1,263)$ (excl. instruments) & $174.98 * * *$ \\
\hline
\end{tabular}

Sample: Soep-Data. The proportion of prime age (25-45) computer users is calculated on the "3-digit" occupational level. Number of employees aged 50-62 in 1997 with information about the employment status until 2003 and information about computer usage is 765 . Clustered (on the 3-digit occupational level) standard errors are in parentheses. 
Table 8: Instrumental Variables Regressions Explaining "Still Working"

\begin{tabular}{lccccc}
\hline \hline & \multicolumn{5}{c}{ Dep. Variable: Person is Still Working in... } \\
\hline Panel A: & $\ldots 1998$ & $\ldots 1999$ & $\ldots 2000$ & $\ldots 2002$ & $\ldots 2003$ \\
Computer User & $0.089^{* *}$ & $0.058^{* * *}$ & $0.034^{*}$ & 0.087 & 0.053 \\
& $(0.045)$ & $(0.023)$ & $(0.019)$ & $(0.058)$ & $(0.080)$ \\
Controls & Age & Age & Age & Age & Age \\
\hline Panel B: & & & & \\
Computer User & 0.095 & $0.071^{* *}$ & 0.049 & -0.013 & -0.073 \\
& $(0.063)$ & $(0.033)$ & $(0.035)$ & $(0.083)$ & $(0.096)$ \\
Controls & Age, Educ., & Age, Educ., & Age, Educ., & Age, Educ., & Age, Educ., \\
& Gender & Gender & Gender & Gender & Gender \\
\hline \hline
\end{tabular}

Sample: Soep-Data. Computer usage is instrumented for by the proportion of prime age (25-45) computer users within the same "3-digit" occupation. Number of employees aged 50-62 in 1997 with information about the employment status until 2003 and information about computer usage is 765. Clustered (on the 3-digit occupational level) standard errors are in parentheses. 


\section{Conclusions}

During the 1980s and 1990s several law changes in the unemployment compensation system were enacted in Germany affecting certain groups of workers, leaving the remainder of the labor force unaffected. This paper takes advantage of the experiment provided by these law changes to analyze the question of whether the wide spread of IT at the workplace in recent decades has had a harmful impact on the labor market position of older workers.

The theoretical link between the unemployment compensation system and the adoption of new technology is the disincentive to invest in human capital provided by an extension of the generosity of the system. Using a differences-in-differences strategy, I show that the computer usage rates of different age groups closely match the the law changes. In 1979, when the maximum entitlement period for unemployment benefits was 12 month for all employees, IT usage rate were flat over all ages. During the 1980s and mid-1990s, when the unemployment compensation system got increasingly generous for younger and younger employees, the IT usage rates of affected groups decreased accordingly. By contrast, after the reform in April 1997, which cut back the generosity of unemployment benefits, affected groups catched up in terms of IT usage. 


\section{References}

Aubert, P., Caroli, E. and Roger, M. (2004). New Technologies, Workplace Organization and the Age Structure of the Workforce: Firm-Level Evidence, Document de Travail G 2004/0\%, INSEE.

Autor, D., Levy, F. and Murnane, R. (2003). The Skill Content of Recent Technological Change: An Empirical Exploration, Quarterly Journal of Economics 118(4): 12791333 .

Berkel, B. and Börsch-Supan, A. (2004). Pension Reform in Germany: The Impact on Retirement Decision, Discussion Paper 62-2004, MEA.

Bertschek, I. (2004). Führt IT-Nutzung zu altersfeindlicher Reorganisation der Arbeit? Eine Untersuchung auf Grundlage der IKT-Umfrage des ZEW, in B. Fitzenberger, W. Smolny and P. Winkler (eds), Herausforderungen an den Wirtschaftsstandort Deutschland, Vol. 72 of ZEW Wirtschaftsanalysen, Baden-Baden, pp. 249-263.

Borghans, L. and ter Weel, B. (2002). Do Older Workers Have More Trouble Using a Computer Than Younger Workers, The Economics of Skill Obsolescene 21: 139-173.

Borjas, G. (2000). Labor Economics, Irwin McGraw-Hill, Boston.

Börsch-Supan, A. and Schnabel, R. (1999). Social Security and Declining Labor Force Participation in Germany, American Economic Review 88: 173-178.

Card, D. (1999). The Causal Effect of Education on Earnings, in O. Ashenfelter and D. Card (eds), Handbook of Labor Economics, Elsevier Science, Amsterdam, pp. 1801-1863.

Card, D. and DiNardo, J. (2002). Skill Biased Technological Change and Rising Wage Inequality: Some Problems and Puzzels, Journal of Labor Economics 20(4): 733-783.

Card, D. and Krueger, A. (1994). Minimum Wages and Employment: A Case Study of the Fast-Food Industry in New Jersey and Pennsylvania, American Economic Review 84(4): $772-793$.

Clemens, W., Künemund, H. and Parey, M. (2003). Erwerbsbeteiligung und der Arbeitsmarkt, in M. Herfurth, M. Kohli and K. Zimmermann (eds), Arbeit in einer alternden Gesellschaft, Sozialwissenschaften im Überblick, Leske + Budrich, Opladen, pp. 2141.

Fitzenberger, B. and Wilke, R. (2004). Unemployment Duration in West-Germany Before and After the Reform of the Unemployment Compensation System during the 1980s, Discussion Paper 04-24, ZEW Mannheim.

Friedberg, L. (2003). The Impact of Technological Change on Older Workers: Evidence from Data on Computer Use, Industrial and Labor Relations Review 56(3): 511-529.

Hunt, J. (1995). The Effect of Unemployment Compensation on Unemployment Duration in Germany, Journal of Labor Economics 13(1): 88-120.

Layard, R., Nickell, S. and Jackman, R. (1991). Unemployment: Macroeconomic Performance and Unemployment, Oxford University Press, New York. 
Spitz, A. (2004). Are Skill Requirements in the Workplace Rising? Stylized Facts and Evidence on Skill-Biased Technological Change, Discussion Paper 04-33, ZEW Mannheim.

Weinberg, B. (2002). New Technologies, Skill Obsolescence, and Skill Complementarity, in A. De Grip, J. Van Loo and K. Mayhew (eds), Research in Labor Economics Vol.21. The Economics of Skill Obsolescence, Amsterdam, pp. 101-118. 